\title{
PROGRAMME OF SESSIONS
}

\section{MONDAY, 5 SEPTEMBER 2005}

\section{Climate and environment records from ice cores}

Yao T., Wen L., L.G. Thompson, E. Mosley-Thompson, Tian L., Wang N. and Duan K.: $\delta^{18} \mathrm{O}$ record in Tibetan ice core reveals differences in climatic changes

Xiang S., Yao T., Wu G., An L., Chen Y., Shang T., Pu L. and Zhang X.: Bacterial populations within the Muztag Ata Mountain Glacier correlate with climatic and environmental changes

M. Schwikowski, S. Brütsch, G. Casassa and A. Rivera: A potential high-elevation ice core site at the Southern Patagonian Icefield

D. Bolius, M. Schwikowski, T. Jenk, H.W. Gäggeler and G. Casassa: A first shallow firn core record from Glacier La Ollada on Cerro Mercedario in the Central Argentinian Andes

Han J., M. Nakawo, K. Goto-Azuma and Lu C.: Impact of air burden fine dust on mass balance of high mountainous glaciers

Wang, N., Yao, T., L.G. Thompson and M.E. Davis: Strong negative correlation between dust event frequency and air temperature over the Northern Tibetan Plateau reflected by the Malan ice core record

M.E. Davis and L.G. Thompson: An Andean ice core record of a Middle Holocene Mega-Drought in North Africa and the Middle East

E. Mosley-Thompson, L.G. Thompson and Lin Ping-nan: A multi-century ice core perspective on 20th century climate with new contributions from high Arctic and Greenland PARCA cores

V.B. Aizen, E.M. Aizen, D.I. Joswiak, K.Fujita, L.N. Takeuchi, K.J. Kreutz and S.A. Nikitin: Climatic and atmospheric circulation pattern variability from ice-core isotope/geochemistry records (Altai, Tien Shan and Tibet)

L.G. Thompson, Yao T., M.E. Davis, E. Mosley-Thompson, Lin P.-N., T.A. Mashiotta, V.N. Mikhalenko and V.S. Zagorodnov: Holocene climate variability archived in the Puruogangri ice cap from the central Tibetan Plateau

Wang Y., Yao T., Wang N., Tian L. and Pu J.: Influence of the Indian Monsoon on the $\delta^{18} \mathrm{O}$ recorded in the Malan ice core on the Tibetan Plateau

Kang S., Qin D., P.A. Mayewski, S. Kaspari, Ren J. and Hou S.: Climatological significance of ice core $\delta$ D records from the Mt Nyainqentanglha, southern Tibetan Plateau

J. Uetake, S. Kohshima, F. Nakazawa, K. Suzuki, M. Kohno, T. Kameda, S. Alkhipov and Y. Fujii: Biological ice core analysis in the Sofiyskiy Glacier, Altai mountains, Russia

T. Segawa, N. Takeuchi and S. Kohshima: Altitudinal change in bacterial flora on the Gulkana Glacier, Alaska, analyzed by 16S rRNA gene

Kumiko Goto-Azuma, Takayuki Shiraiwa, Sumito Matoba, Takahiro Segawa, Syosaku Kanamori, Yoshiyuki Fujii and David A. Fisher: A 100-year ice core record from King Col, Mount Logan, Canada

\section{TUESDAY, 6 SEPTEMBER 2005}

\section{Glacier variations}

Shangguan Donghui, Liu S., Ding Y., Ding L., Xiong L., Li Gang, Lu A., Zhang S. and Zhang Y.: Monitoring the glacier changes in the Muztag Ata and Konggur Mountains on the east Pamirs plateau with $\mathrm{CBI}$ and Landsat TM/ETM ${ }^{+}$

Gou Xiaohua, Chen F. and Yang M.: The tree-ring records and glacier variations in the northeastern Tibetan Plateau

Liu S., Ding Y., Shangguan D., Zhang Y., Li J., Han H., Wang J. and Xie C.: Glacier retreat under a warming and wetting change of climate in the Tarim River Basin, northwest China

Koji Fujita: Vulnerable Himalayan glaciers

Ding Y. and Liu S.: The retreat response of glaciers to recent climate warming in the western China

Shi Yafeng, Liu Shiyin and Shangkuan Donghui: Two peculiar phenomena on climatic and glacial variation in the Tibetan Plateau

A. Lambrecht, R. Würländer and M. Kuhn: The new Austrian glacier inventory, a tool for the investigation of glacier change

A. Rivera, F. Bown, R. Mella, J. Wendt, G. Casassa, C. Acuña, E. Rignot and J. Clavero: Ice volumetric changes on active volcanoes of Southern Chile

K. Nicolussi, K.F. Kaiser, G. Patzelt and P. Schooling: Glacier advances and retreat periods during the 1st millennium AD in the eastern European Alps

C. Mayer, A. Lambrecht, M. Belò, C. Smiraglia and G. Diolaiuti: Glaciological characteristics of the ablation zone of Baltoro Glacier, Karakoram

\section{Poster session}

Yang, M., Yao T., Wang H. and Gou X.: Wavelet analysis of the periodic oscillations in ice core records of the past 1700 years from Guliya, China

Yang M., Yao T., Wang H. and Gou X.: Correlation between precipitation and temperature variations in the past 300 years recorded in Guliya Ice Core, China

S. Matoba, I. Mori, M. Nishikawa, T. Shiraiwa, K. Goto-Azuma and Y. Fujii: Estimation of dust sources in the Logan Ice Core using Th/U ratios of dust

T. Miyake, F. Nakazawa, H. Sakugawa, N. Takeuchi, K. Fujita, K. Ohta and M. Nakawo: Concentrations and source variations of $n$-alkanes in a $21 \mathrm{~m}$ ice core and snow samples at Belukha Glacier, Russian Altai Mountains

Y. Yoshimura, S. Kohshima, N. Takeuchi, K. Seko and K. Fujita: Snow algae in a Himalayan ice core: new environmental markers for ice core analyses and their correlation with summer mass balance 
Zhang X., Yao T., A. Lishe, Tian L. and X. Hujian: Bacterial community profile in Puruogangri ice core and its relation to climatatic and environmental fluctuation

Li Z., L.G. Thompson, E. Mosley-Thompson, Hou S. and Wang F.: The chronology and record formation process of an ice core from Glacier No. 1 at the Urumuqi River Head, in eastern Tianshan, China

F. Nakazawa and K. Fujita: Reconstructing of mean summer air temperature variations with an ice cores from summer-accumulation-type glaciers

Hou S., Ren J., and Qin D.: Modification of three ice core $\delta^{18} \mathrm{O}$ records from area of high melt

Kumiko Goto-Azuma, Roy M. Koerner and Okitsugu Watanabe: Spatial variation of snow chemistry on Mount Logan, Yukon, Canada

Liu Yongqin, Yao Tangdong, Tian Lide, Xu Baiqin and Wu Guanjian: Glaciochemical records from Namunani ice core in Himalayans

Lu A., He Y., Zhang Z., Pang H., Yuan L. and Ning B.: Glacier retreat under global warming - a disaster for the arid area of northwest China

Liu S., Shangguan D. Ding Y., Han H., Xie C., Zhang Yong, Li Jing, Wang J. and Li G.: Glacier changes during the past century in the Gangrigabu Mountain, Southeast Tibetan Plateau, China

J.L. Ceballos, C. Euscátegui, J. Ramírez, M. Cañon, C. Huggel, W. Haeberli and H. Machguth: Fast shrinking of tropical glaciers in Colombia Lu A., Yao T., Wang L., Liu S. and Guo Z.: The study of typical glaciers and lakes fluctuations using remote sensing in Qinghai-Tibetan Plateau Jing Zhe-fan, Jiao Ke-qin, Yao Tan-dong and Wang Ning-lian: Fluctuations of the Glacier No. 1 at the headwaters of the Ürumqi river in the Tianshan Mountains

N. Naito, R. Suzuki, Y. Matsuda, Y. Ageta, K. Fujita, T. Yamada and K. Karma: Contrastive variations of Lugge and Thorthormi Glaciers in the Bhutan Himalayas - effect of a huge proglacial lake to the glacier shrinkage

V.B. Aizen, V.A. Kuzmichenok, A.B. Surazakov and E.M. Aizen: Glacier changes in central and northern Tien Shan during the last 150 years based on surface and remote sensing data

Ren J., Jing Z., Pu J. and Qin X.: Glacier variations and climate change in the central Himalayas over past decades

C. Narama, Y. Shimamura, D. Nakayama and K. Abdrakhmatov: Recent glacier changes in the Terskey-Alatoo range, Kyrgyz Republic, using Corona and Landsat

W. Wang, V. Morgan, J. Zwally and M. Beckley: Historic ice-sheet accumulation rate and thickness change inferred from radar-detected internal layers at Law Dome Summit, East Antarctica

K. Yalcin, C.P. Wake, K.J. Kreutz and S.I. Whitlow: Seasonal and spatial variability in snow chemistry at Eclipse Icefield, Yukon Territory, Canada Zhao Z., Li Z., Li X., You X., Wang F., Li C., Li H. and Zhu Y.: Atmosphere-to-snow-to-firn transfer of $\mathrm{NO}_{3}{ }^{-}$at Glacier No. 1, Tienshan, China

You X., Li Z., Wang F., Li H., Li C., Li X., Zhao Z. and Zhu Y.: The behavior of microparticles in air and snowpack on Glacier No. 1 at Ürümqi riverhead in eastern Tianshan, China

Wang F., Li Z., You X., Li C., Li H., Li X., Zhao Z. and Zhu Y.: Seasonal variation and evolution process of $\mathrm{Mg}^{2+}$ and $\mathrm{Ca}^{2+}$ in snow-firn pack on Glacier No. 1 at Ürümqi riverhead, the eastern Tianshan, China

Li C., Li Z., Wang R., You X., Li X., Li H., Zhao Z. and Zhu Y.: The preliminary research of the trace metals in snow-firn at Glacier No. 1, the East Tianshan, China

Hou S., Zhang D., Qin D. and Ren J.: Major ions of two snow pits from the central High Himalayas

\section{WEDNESDAY, 7 AUGUST 2005}

\section{Interaction between snow/ice and atmosphere}

Li X., Li Z., Zhao Z., Li H., You X., Li C., Wang F. and Zu Y.: Seasonal variations and evolution processe of pH and electrical conductivity in snow-firn pack at Glacier No. 1, Tianshan, China

Li Y., Yao T., Li Z., Tian L., Xu B. and Wu G.: Heavy metals in a high elevation ice core from Muztag Ata in east Pamir Mountain: initial results

Li Z., R. Edwards, E. Mosley-Thompson, Wang F., You X., Li C., Zhao Z., Li H., Li X. and Zhu Y.: Seasonal variabilities of ionic concentrations in surface snow and elution process in sno-firn packs at PGPI site on Glacier No. 1, in eastern Tianshan, China

M. Vuille, M. Werner and R.S. Bradley: Stable isotopes in precipitation and the Asian monsoon models and observations

Xu Baiqing, Yao Tandong, Liu Xianqin and Wang Ninglian: Elemental carbon and organic carbon measurements with a two-step heating-GC system in the snow samples from Tibetan plateau

N.J. Cullen, T. Mölg, D.R. Hardy and G. Kaser: Understanding glacier recession on Kilimanjaro from automatic weather station data

\section{Glacial deposits and climate change}

V. Wasiuta, A.-L. Norman and S.J. Marshall: Spatial patterns and seasonal variation of snowpack sulphate of the Prince of Wales Icefield, Ellesmere Island

Yu W. , Yao T., Tian L., Wang Y. and Sun W.: Oxygen-18 isotopes in precipitation on the eastern Tibetan Plateau

Katsuhiko Asahi: Last glacial equilibrium-line altitude reconstruction in the eastern Nepal Himalayas and their implications for past monsoon climate

\section{THURSDAY, 8 AUGUST 2005}

\section{Glacio-hydrological processes}

He Y., Pang H., W.H. Theakstone, Lu A., Zhang Z., Zhang D., Yuan L. and Song B.: Spatial and temporal variations of oxygen isotopes in snowpacks and glacial runoff in different types of glacial area in Western China

Xie C., Ding Y., Liu S. and Han H.: Characteristics glacio-hydrological variations in the Keqikaer Glacier by the cross-spectral analysis Zhang Y. and Liu S.: Application of degree-day model for glacier meltwater on Glacier Keqicar Baqi, southwest Tianshan

Liu J., Shen Y., Liu S. and Huang Y.: Impact of summer meltwater to subsurface flow in glacier covered mountain watersheds, West China

I. Juen, P. Wagnon, G. Kaser and B. Pouyaud: One year of energy balance on glacier Artesonraju in the tropical Cordillera Blanca, Peru. Measured and modelled ablation and runoff.

F. Ng, Liu S. and B. Mavlyudov: Modelling the long-term outburst dynamics of Lake Merzbacher, Tian Shan

H. Jay Zwally, J.L. Saba and and K. Steffen: Melt-flow acceleration near the equilibrium line of the Greenland Ice Sheet: spatial gradient and interannual variability 


\section{Glacier physics}

Wu Guanjian, Yao T., Li Z., Li Y., Xu B., Li Z. and Tian L.: Mircoparticle and anion records in a Muztagata ice core

Wang Feiteng, Li Z., Liu B., You X., Li C., Li X. and Li H.: A study on the transformation process of snow to ice in the percolation zone of the Glacier No. 1 at Ürümqi riverhead, the eastern Tianshan, China

V. Zagorodnov, O. Nagornov and L.G. Thompson: Influence of surface climatic conditions on glacier's active layer temperature

\section{Poster session}

Zhao Jingdong, Liu S., He Y., Deng X. and Shangguan D.: A study of the glacial landforms and ice ages of the Ateaoyinake River Valley, the southern slope of the Tumer Peak, Tianshan Mountains, China

Deng Xiaofeng, Zhao J. and Liu S.: A study of loess-paleosol sediment sequence and climate change in Holocene on the southern slope of Tumer Peak, China

Xu Liubing and Zhou S.: Pleistocene glaciations in the Shaluli Mountain and the influences of southwest monsoon on the glaciations during the last glacial period

C. Narama and M. Okuno: Timing of glacier variations during the Last Glacial Period in the Turkestan Range of the Pamir-Alai

Wang Xiaoli, Zou Songbing and Zhou S.: The coupled model of the glacial and the climatic changes of the Southeast Nyanqingtanggula Mountain on the Qinghai-Tibetan Plateau, China

C. Mihalcea, C. Mayer, G. Diolaiuti, A. Lambrecht, C. Smiraglia and G. Tartari: Ice ablation and meteorological conditions on the debris covered area of Baltoro Glacier (Karakoram, Pakistan)

Li Zhen, Yao T., Tian L., Xu B., Wu G. and Zhu G.: Borehole temperatures at the ice-core drilling sites in the Muztag Ata Glacier, East Pamirs Zhao Hua-biao, Yao T. and Xu B.: Hydrological and hydrochemical features of Kaltamak Glacier area in the Mt Muztag Ata

You Xiaoni, Li Z., Wang F., Li H., Li C., Li X. and Zhao Z.: Study on time scale of snow-ice transformation at PGPI site on Glacier No. 1 at the Ürümqi riverhead, in eastern Tianshan, China

Yong Zhang and Liu S.: Degree-day factor for the observed glacier and its spatial variation, Western China

R.J. Braithwaite, S.C.B. Raper and K. Chutko: A new approach to the climatic classification of glaciers

S. Yamaguchi, M. Lehning, K. Fujita, A. Sakai, Y. Matsuda and H. Narito: Simulation of superimposed ice at July 1st Glacier, Qi-lian Mountains, China

G. Casassa, A. Rivera, J. Wendt, F. Bown and C. Acuña: Computation of glacier mass balance in southern Chile based on GPS

Pu Jianchen, Yao T., Tian L., Zhang Y., Y. Ageta and K. Fujita: Mass balance and its change of the small Dongkemadi Glacier in the QinghaiTibetan plateau

O. Nagornov, Y. Konovalov and V. Mikhalenko: Prediction of thermodynamic state of the Gregoriev Ice Cap (Tien Shan, Central Asia) in the future

Xie Zi-chu, Wang Xin, Feng Qing-hua, Kang Ersi and Deng Yuwu: Modeling the response of glacier system to climate warming in China

Yang Meixue, Yao T. and Wang H.: Effect of the very heavy snow on the ground temperature in the Northern Tibetan Plateau

Ling Fent, Zhang T. and Yang M.: Numerical analysis for effects of snow on the surface energy fluxes and ground thermal regime on the QinghaiTibet Plateau, China

\section{FRIDAY, 9 AUGUST 2005}

\section{Glacier mass balance and modelling}

Ye Baisheng, Ding Y., Liu S. and Shen Y.: Response of glacier runoff to climatic warming during 1980-2003 in the Glacier No. 1 at the headwater of Ürümqi River, northwest China

Han Tianding, Ding Y., Ye B., Liu S., and Jiao K.: Characteristics of mass balance of Glacier No. 1 at the headwaters of the Ürümqi River, Tianshan Mountains

H. Machguth, F. Paul, M. Hoelzle and W. Haeberli: Distributed glacier mass balance modelling as an important component of modern multilevel glacier monitoring

R.J. Braithwaite, S.C.B. Raper and K. Chutko: Accumulation at the equilibrium line altitude (ELA) of glaciers inferred from a degree-day model and tested against field observations

Dong Cai: Mass balance of Nyainqen Tanglha Glacier, Tibet, 1977 to 2001, derived by topographical maps and satellite images

Wen Jiahong, K.C. Jezek, A.J Monaghan and Sun B.: Accumulation variability and mass budgets of the Lambert Glacier-Amery Ice Shelf system at high elevations

Y. Matsuda, K. Fujita, Y. Ageta and A. Sakai: Estimating transmissivity of solar radiation for glacier mass balance modeling in the Himalayas and Tibetan Plateau

W. Wang, Li Jun and H. Jay Zwally: Modeling of the dynamic characteristics along flowline from Dome A to Amery ice shelf, East Antarctica Wang Xin, Xie Z., Feng Q., Yang Y. and Yang M.: Modelling the roles of precipitation increasing in glacier system response to climate warming taking Xinjiang region as an example

Jun Li and H. Jay Zwally: Melting effect on snow densification and surface elevation change over Greenland Ice Sheet

A. Schwerzmann, M. Funk and H. Blatter: Flow modelling, borehole logging and ice core interpretation at Fiescherhorn glacier, Swiss Alps

\section{Snow cover and related processes}

Pang Hongxi, He Y., Lu A., Zhao J.. Song B., Ning B. and Yuan L.: Influence of Eurasia snow cover in spring on the Indian Ocean dipole K. Rikiishi and H. Nakasato: Height-dependence of the declining tendency of the seasonal snow cover in the Himalaya Mountains region during the years 1966-2001

Nozomu Takeuchi, J. Uetake, K. Fujita, V. Aizen and S. Nikitin: A snow algal community on Akkem glacier in the Russian Altai Mountains Zhou S., M. Nakawo, S. Hashimoto and A. Sakai: Preferential exchange rate effect of isotopic fractionation in melting and re-frozen snow Atsumu Ohmura: Changes of mountain glaciers and small ice caps during the 20th century and the future prospect in a warming climate Duan Keqin, Yao T., Tian L., Xu B. and Wu G.: Variability of snow accumulation at the site with elevation of $7010 \mathrm{~m}$ a.s.l. in Muztag Ata Mountain in Pamir Plateau 